\title{
Leukoencephalomalacia in horses associated with immature corn consumption
}

\author{
Joanna Vargas Zillig Echenique ${ }^{1}$ Pablo Estima-Silva ${ }^{1}$ Daniela Brayer Pereira ${ }^{1,2}$ \\ Lucas Santos Marques ${ }^{3}$ Luiza Soares Ribeiro ${ }^{3}$ Ana Lucia Schild ${ }^{4 *}$ iD
}

${ }^{1}$ Programa de Pós-Graduação em Veterinária, Faculdade de Veterinária, Universidade Federal de Pelotas (UFPel), Capão do Leão, RS, Brasil. ${ }^{2}$ Instituto de Biologia, Departamento de Parasitologia e Microbiologia, Universidade Federal de Pelotas (UFPel), Capão do Leão, RS, Brasil. ${ }^{3}$ Laboratório Regional de Diagnóstico (LRD), Universidade Federal de Pelotas (UFPel), Pelotas, RS, Brasil.

${ }^{4}$ Laboratório Regional de Diagnóstico, Universidade Federal de Pelotas (UFPel), 96010-900, Campus Universitário Capão do Leão, Capão do Leão, Pelotas, RS, Brasil. E-mail: alschild@terra.com.br. "Corresponding author.

ABSTRACT: Horse leukoencephalomalacia (ELEM) is a disease caused by the ingestion of mycotoxins (fumonisins) produced by fungi of the genus Fusarium that infect corn and/or its byproducts. This disease has been described by ingestion of mature corn with humidity above $15 \%$ at temperatures below $20^{\circ} \mathrm{C}$. The aim of this paper was to report an outbreak of leukoencephalomalacia in horses fed with immature corn. Two horses out of three showed neurological signs approximately seven days after eating immature corn in its reproductive phase ( $R 2$, milky grains). Corn was harvested and administered directly to the animals, with no storage. Deaths occurred approximately 24 hours after the onset of clinical signs. Grossly, there were multifocal dark red to brown areas in the white matter of the telencephalon and hyppocampus and thalamus. Histologically, there was edema and hemorrhage in several areas of the telencephalon white matter, which corresponded to dark red to brown areas observed in the macroscopy. There was also foci of malacia with presence of reactive astrocytes with abundant eosinophilic cytoplasm and inflammatory cells. Diffuse capillary wall degeneration and endothelial cell swelling were also observed. Two ppm of fumonisin were detected by immunoaffinity column method (VICAM) in the immature corn sample. The water activity in this cereal, when the grain is still milky, is 0.98 and can predispose it to growth of mycotoxin-producing fungi. In the present case, fumonisin was found in milky grains in the beginning of the reproductive phase (R2), which suggested that even immature corn may be infected by Fusarium spp. and should not be administered to horses.

Key words: fumonisin, water activity, cereals, central nervous system, horse.

Surto de leucoencefalomalacia em equinos associado ao consumo de milho verde

RESUMO: A leucoencefalomalácia dos equinos (ELEM) é uma doença causada pela ingestão de micotoxinas (fumonisinas) produzidas por fungos do gênero Fusarium que infectam o milho elou seus subprodutos. A doença tem sido descrita pela ingestão de milho maduro com umidade acima de $15 \%$ em temperatura ambiente abaixo de $20^{\circ} \mathrm{C}$. O objetivo deste trabalho foi relatar um surto de leucoencefalomacia em equinos alimentados com milho verde. Dois equinos de três animais apresentaram sinais clínicos neurológicos aproximadamente sete dias após iniciarem a ingestão de milho verde na fase reprodutiva ( $R 2$, grãos leitosos) com palha e talos, colhido no máximo 24 horas antes de ser administrado. A morte ocorreu aproximadamente 24 horas após o inicio dos sinais clínicos. Macroscopicamente havia no sistema nervoso central áreas multifocais acinzentadas e amareladas na substância branca do telencéfalo, no hipocampo e no tálamo. Histologicamente observou-se edema e hemorragia em diversas áreas da substância branca do telencéfalo, que correspondiam às áreas acinzentadas observadas na macroscopia. Havia, também, próximo as áreas hemorrágicas, focos de malacia com presença de astrócitos reativos com abundante citoplasma eosinophilico e algumas células inflamatórias. Degeneração das paredes dos capilares e tumefação das células endoteliais também foram observadas. Na análise da amostra de milho pelo método de colunas de imunoafinidade (VICAM) foram detectados 2ppm de fumonisina. A atividade de água neste cereal, quando o grão ainda está leitoso, é de 0,98, o que predispõe ao crescimento de fungos produtores de micotoxinas. No presente caso fumonisina foi encontrada nos grãos leitosos no início da fase reprodutiva (R2), o que sugere que mesmo o milho ainda imaturo pode estar infectado por Fusarium spp. e não deve, também, ser administrado aos equinos.

Palavras-chave: fumonisina, atividade de água, cereais, sistema nervoso central, equinos.

Horse leukoencephalomalacia (ELEM) is a disease caused by the ingestion of mycotoxins (fumonisins) produced by fungi of the genus Fusarium, including $F$. proliferatum and $F$. verticillioides (Fusarium moliniforme). The disease has been described in equine fed corn grains, its byproducts (corn roll, broken corn and ground corn), corn-based pelleted or non-pelleted feed, and bran (WILSON et al., 1990, MEIRELES et al., 1994). ELEM was also described in horses fed hay, oats and mixtures of cereal screenings (WILSON et al., 1990, VENDRUSCOLO et al., 2016). Temperatures below $20^{\circ} \mathrm{C}$ and environmental humidity of $15 \%$ or higher predisposes to fumonisin production by Fusarium 
spp., associating the disease with cold seasons (RIET \& MÉNDEZ 2007; ALBERTS et al., 1990). In the southernmost region of Brazil, ELEM occurs in the months of June to September (MEIRELES et al., 1994), but there are records of ELEM between March and December in the northern area of the country (CÂMARA et al., 2008, GIANNITTI et al., 2011).

Fungal proliferation, including Fusarium spp. in corn, also depends on the grain's water activity (wa). Values ranging from zero to 0.20 indicate that water is strongly bound, while values ranging from 0.70 to 1.00 indicate that the majority of water molecules are unattached and can be used in chemical and enzymatic reactions, in addition to the development of microorganisms (CUNHA, 2018). Grain corn in the milky or pasty phase has a water activity of approximately 0.98 , which can influence and enhance fungal growth.

Horses are especially sensitive to fumonisin poisoning and there are no safe levels for this species. Cases may occur with concentrations less than 1ppm, but most poisonings occur with greater than 10ppm (ROSS et al., 1991). Clinical signs are drowsiness, depression, ataxia, tremors, compulsive walking and head pressing against objects and death occurs within 24-48 hours. Lesions are localized in the white matter of the cerebral cortex and brain stem and are characterized by liquefactive necrosis, edema and hemorrhage. Histologically, there is necrosis of the white matter, edema, multifocal hemorrhages and inflammatory infiltrates of neutrophils, eosinophils and foamy macrophages. Vascular alterations can also occur, such as vascular endothelial edema, perivascular edema, hemorrhage and occasionally perivascular cuffing (MEIRELES et al., 1994, GIANNITTI et al., 2011). Lesions may not be present in discrete cases.

The aim of the present paper was to describe the epidemiological characteristics of an ELEM outbreak associated with the consumption of immature corn.

Two out of three horses belonging to a farm located at the municipality of Canguçu, RS, Brazil displayed neurological signs and death within 24 hours. On visiting the farm, a necropsy of one of the horses was performed. Epidemiological data and clinical signs were investigated. During the necropsy, samples of all organs and the central nervous system (CNS) were obtained, fixed in $10 \%$ buffered formalin, routinely processed, and stained with hematoxylin and eosin (HE). Corn samples containing all parts were collected and sent to the Laboratório de Pesquisas Micológicas/Universidade
Federal de Santa Maria for the determination of the presence and quantification of fumonisins.

According to the owner, horses exhibited hind limb rigidity, unawareness of their surroundings, proprioceptive deficits, loss of balance, aimless circling, recumbency with paddling and death within 24 hours after the onset of clinical signs. The animals were eating corn that was still immature in the beginning reproductive stage, which was harvested directly from the field with tassels, stalks, leaves, tillers, cob and kernels (Figure 1A). This corn was administered to the horses within one day after harvest. Horses ingested the corn approximately seven days before the onset of clinical signs. After the corn withdrawal, there were no more cases in the farm.

Grossly, brain exhibited dark red to brown multifocal rounded areas $2-3 \mathrm{~cm}$ in diameter on the cut surface of the white matter of the telencephalon (Figure 1B). Additionally, areas of hippocampus e thalamus exhibited yellowish extents around the lesions (edema) adjacent to the dark red to brown areas. Histologically, there was neuropil edema and hemorrhage in the white matter scattered in several areas of the telencephalon (Figure 1C) and near the hemorrhagic areas foci of malacia, reactive astrocytes and some inflammatory cells were observed (Figure 1C). Along these lesions, degeneration and swelling of the endothelial cells of the capillaries was also observed (Figure 1D). These lesions corresponded to the dark red to brown areas observed grossly.

The diagnosis of ELEM was based on the epidemiology, clinical signs, gross and histologic lesions and the presence of $2 \mathrm{ppm}$ of fumonisin in the immature corn administered to the horses. This mycotoxicosis is familiar to veterinarians and horse owners and has decreased in frequency in RS due to the avoidance of corn in the horse diet, especially in winter. It has been demonstrated that the disease can occur by the ingestion of corn without the presence of visible mold and in corn with less than $15 \%$ moisture (RIET-CORREA et al., 1998). In the present case, the corn was harvested still immature and administered directly to the animals without any storage. The water activity in this cereal, when the grain is still milky, is 0.98 , which can predispose it to mycotoxinproducing fungal growth (HERMANNS et al., 2006). In a fumonisin contamination study, different corn development stages were positive for the toxin presence. The toxin has been reported mainly in the farinaceous grain (R4), hard farinaceous (R5) and physiological maturation (R6) stages (HERMANNS et al., 2006). In the present case; however, 


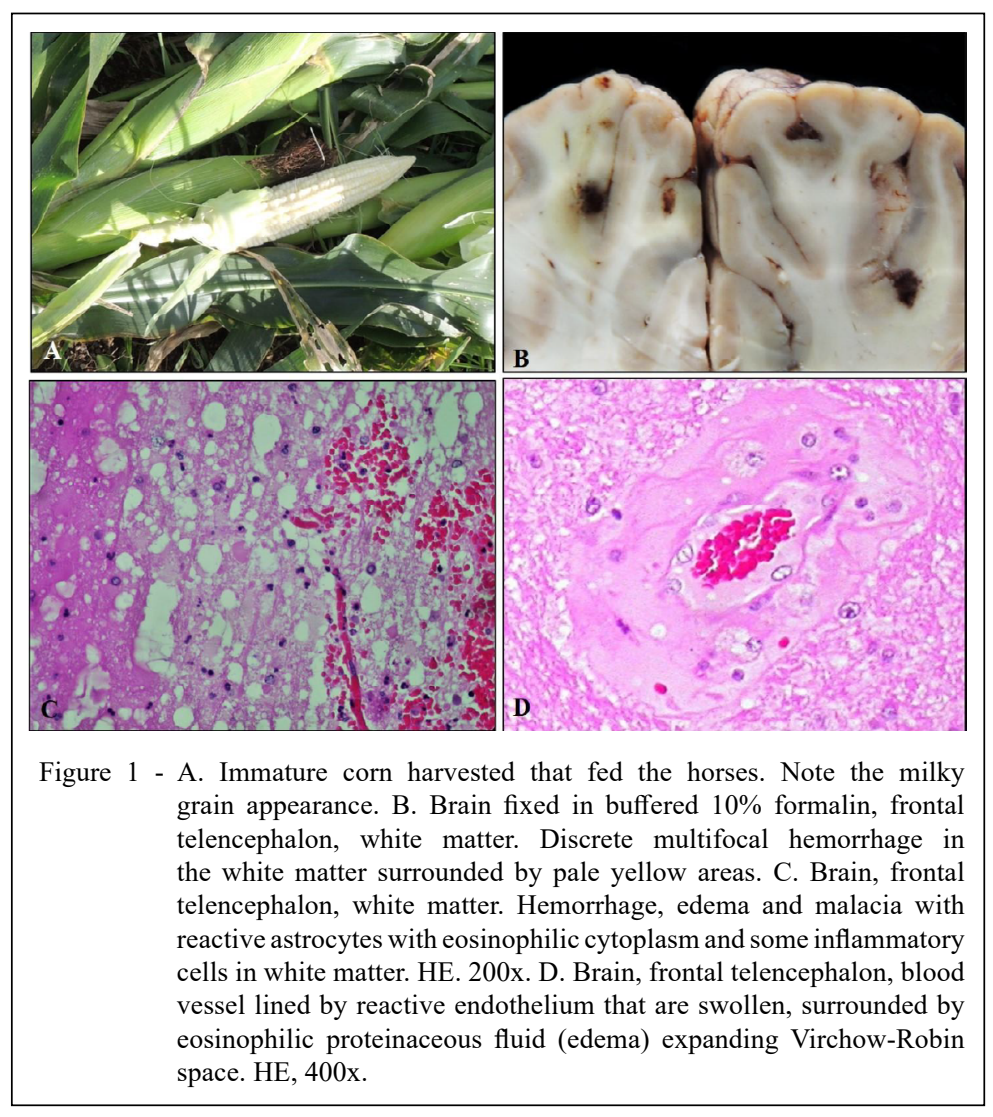

fumonisin was reported in grain at the beginning of its reproductive phase (R2), suggesting that even immature corn can be contaminated with Fusarium spp. Fumonisin toxicity is cumulative and safe levels for horses have not yet been determined. Several studies have attempted to relate the mycotoxin concentration with ELEM, but outbreaks have been described with only $1 \mathrm{ppm}$ in the diet that was offered to the horses (ROSS et al., 1991). Outbreaks reported in the literature have been associated with mature corn and its byproducts; however, corn in the milky grain phase has not yet been described as a cause of ELEM. The lesions observed grossly were discrete, but histologically, the lesions were characteristic of ELEM (RIET-CORREA et al. 1998). This finding suggested that the severity of the lesions is directly linked with the fumonisin concentration. Leukoencephalomalacia should be differentiated from other neurological disorders in horses, such as rabies, horse viral encephalomyelitis, horse herpesvirus type 1 infection, neoplasms and Trema micrantha poisoning. It should be taken into consideration that those diseases have acute onsets similar to that of ELEM. Similar gross lesions can be observed in the neurological form of horse trypanosomiasis (RODRIGUES et al. 2005); therefore, it also should be considered as a differential diagnosis. The history of corn feeding is a key epidemiological factor for the presumptive diagnosis; although, other foods, such as hay, oats, sweet feed and cereal mixtures from surplus crop, can also cause the disease (WILSON et al., 1990, VENDRUSCOLO et al., 2016). This case highlighted that immature corn, without evidence of mold, is an unusual source of fumonisins and can be associate with ELEM. Moreover, in the present report, the fumonisin concentration was linked with the severity of gross and microscopic lesions.

\section{ACKNOWLEDGEMENTS}

The authors are grateful to Conselho Nacional de Desenvolvimento Científico e Tecnológico (CNPq: 305283/20154, 431659/2016-8), Fundação de Amparo à Pesquisa do Estado do Rio Grande do Sul and Coordenação de Aperfeiçoamento de Pessoal de Nível Superior (CAPES) (finance code 001) for scientific, financial support and student's scholarships. 


\section{DECLARATION OF CONFLICTING INTERESTS}

The authors declare no conflict of interest. The founding sponsors had no role in the design of the study; in the collection, analyses, or interpretation of data; in the writing of the manuscript, and in the decision to publish the results.

\section{AUTHORS' CONTRIBUTIONS}

JVZE, PES, DIBP and ALS contributed equally for the conception and writing of the manuscript. LSM and LSR prepared literature revision an carried out the lab histological preparations and lesions description.

\section{REFERENCES}

ALBERTS, J.F. et al. Effects of temperature and incubation period on production of fumonisin B1 by Fusarium moniliforme. Applicated Environmental Microbiology v.56, p. 1729, 1990. Available from: <https://www.ncbi.nlm.nih.gov/pmc/articles/ PMC184501/pdf/aem00087-0233.pdf > . Accessed: Oct. 02, 2018.

CÂMARA, A.C. et al. Leukoencephalomalacia in equines in the State of Pernambuco Ciência Animal Brasileira. v. 9, p.47079, 2008. <https://www.revistas.ufg.br/vet/article/view/1222>. Accessed: Oct. 02, 2018.

CUNHA H.V.F A diferença entre Atividade de Água (Aw) e o Teor de Umidade nos alimentos. 2018. Available from: <https:// foodsafetybrazil.org/diferenca-entre-atividade-de-agua-aw-e-oteor-de-umidade-nos-alimentos/>. Accessed: Aug. 13, 2018.

GIANNITTI, F. et al. Horse leukoencephalomalacia (ELEM) due to fumonisins B1 and B2 in Argentina. Pesquisa Veterinária Brasileira.v.31 n.5, p.407-412, 2011. Available from: <http:// www.scielo.br/pdf/pvb/v31n5/v31n5a07.pdf> Accessed: Aug. 13, 2018. doi: http://dx.doi.org/10.1590/S0100-736X2011000500007.

HERMANNS, G. et al. Fungi and fumonisins in the pre-harvest period of maize. Ciência e Tecnologia de Alimentos. v. 26, n. 1, p. 7-10, 2006. Available from: <http://www.scielo.br/pdf/cta/ v26n1/28841.pdf $>$. Accessed: Aug. 16, 2018. doi: http://dx.doi. org/10.1590/S0101-20612006000100002.

MEIRELES M.C. et al. Mycoflora of the toxic feeds associated with horse leukoencephalomalacia (ELEM) outbreaks in Brazil. Mycopathologia. v.127, n.3, p.183-188, 1994. Available from: $<$ https://www.ncbi.nlm.nih.gov/pubmed/7808512>. Accessed: Aug. 16, 2018.

RIET-CORREA, F. et al. Horse leukoencephalomalacia in Brazil. Toxic plants and other natural toxicants. Wallingford, UK: CAB International. p. 479-482, 1998.

ROSS, P.F. et al. Fumonisin B1 concentrations in feeds from 45 confirmed horse leukoencephalomalacia cases. Journal of Veterinary Diagnostic Investigation. v.3, n.3, p.238241, 1991. Available from: <https://www.ncbi.nlm.nih. gov/pubmed/1911996>. Accessed: Aug. 14, 2018 doi: 10.1177/104063879100300310.

VENDRUSCOLO, C.P. et al. Leukoencephalomalacia outbreak in horses due to consumption of contaminated hay. Journal of veterinary internal medicine. v.30, n.6., p.1879-1881, 2016. Available from: <https://www.ncbi.nlm.nih.gov/pmc/articles/ PMC5115199/>. Accessed: Aug. 14, 2018.

WILSON, T.M. A mycological evaluation and in vivo toxicity evaluation of feed from 41 farms with horse leukoencephalomalacia. Journal of Veterinary Diagnostic Investigation. v.2, n.4, p.352-354, 1990. Available from: < https:// www.ncbi.nlm.nih.gov/pubmed/2095286>. Aug. 14, 2018 doi: $10.1177 / 104063879000200422$. 